Though sheep raisers generally feel that the tests are absolutely necessary, many are suspicious. William Simms, president of the Texas Sheep and Goat Raisers group recently asked: "Who is going to be out there to put this repellant on the lamb when it is born? The mother?"'
But the Interior Department strongl defends predation-control research a "desperately needed." Jack Berryman director of Interior's Wildlife Service Division said that "We can have coyote in abundance and we can protect th sheep industry. We don't have to mak that choice."

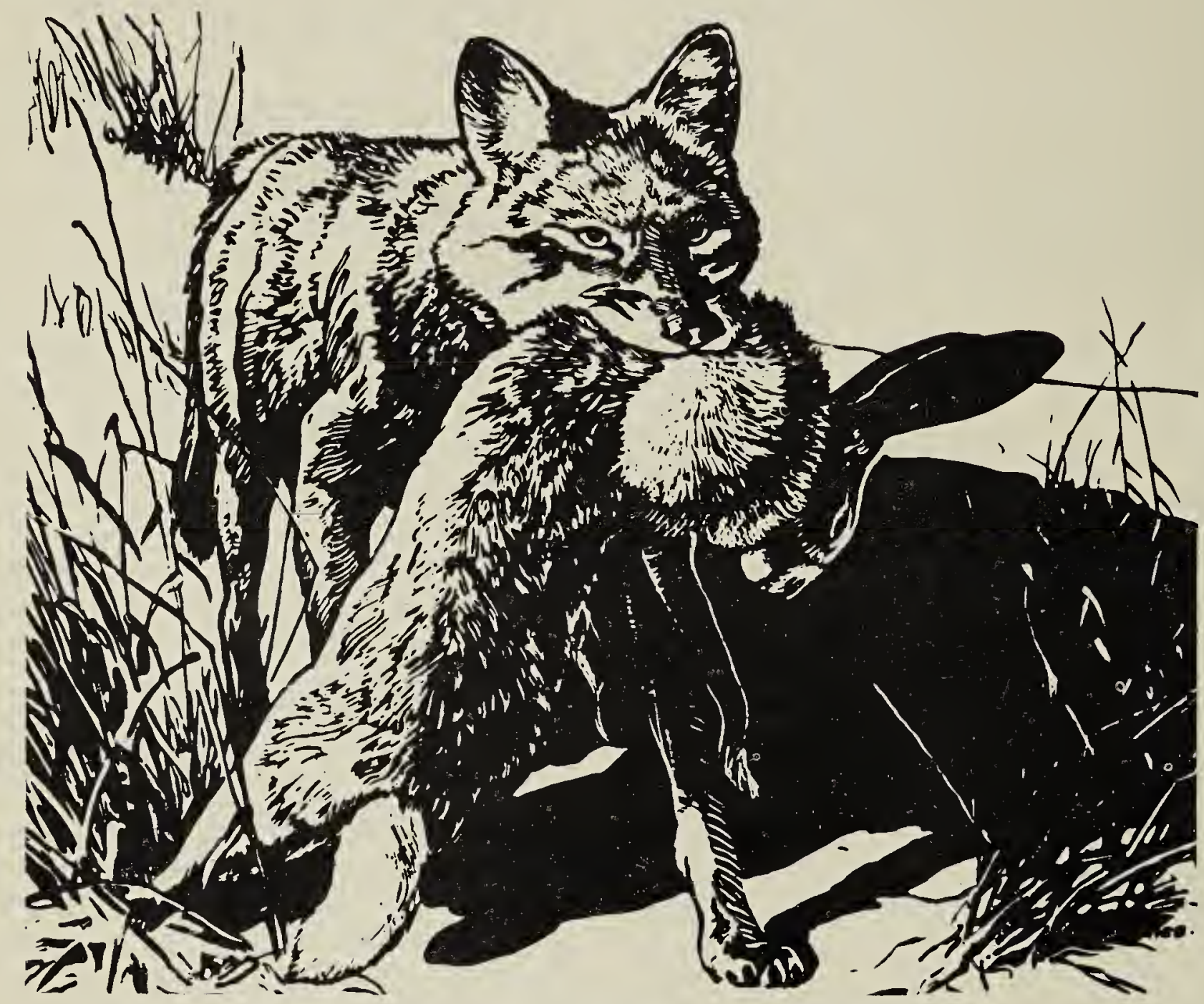

Are you willing to spend an 8-cent stamp for conservation? If so, complete and mail the questionnaire in this issue.

\title{
Additional Records of the BULL SNAKE from Alberta
}

\section{BY GEORGE B. PENDELBURY*}

It is generally well known that the range of the Bull Snake extends into

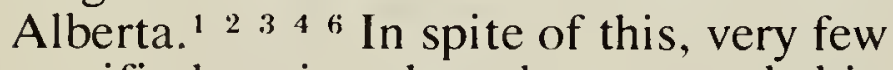
specific locations have been recorded in the literature and the distribution of this snake in the province is yet to be well defined.

The occurrences plotted in Figure 1 are based on several sources of information including (1) published records,

${ }^{*}$ No. 203, 820-5th Ave. S.W. Calgary, Alberta.
(2) specimens in various museums, specimens captured by the writer and $(4$ specimens captured by others an brought to the attention of the writer.

While Bull Snakes are most commo in the southeastern corner of tr province, they are not restricted to th region. The species occurs as far west : Lethbridge and as far north as Hanna The majority of records, however, fa within the range outlined for the speci, by Stebbins." 
published distribution data included on the map. The manuscript was critically read by F. R. Cook who offered suggestions for its improvement.

'Conant, R. 1958. A field guide to reptiles and amphibians of the United States and Canada east of the looth meridan. Houghton Mifflin Co., Boston.

${ }^{2}$ Ditmars, R. L. 1936. The reptiles of North America. Doubleday and Company, Inc., New York.

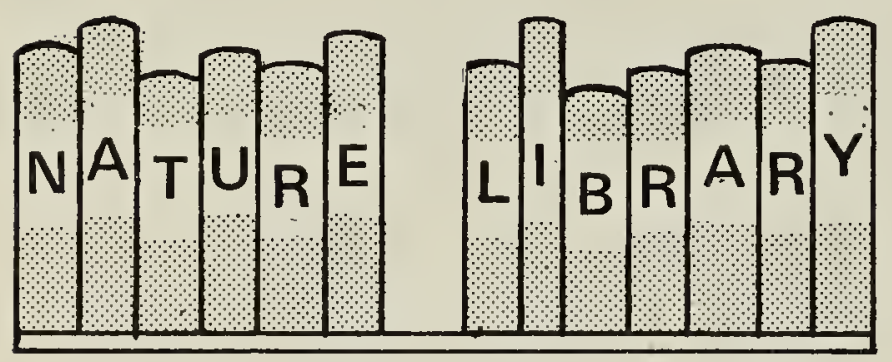

\section{RECENT POPULAR TITLES IN THE NATURAL SCIENCES AT SASKATOON PUBLIC LIBRARY}

\section{Compiled by DIANE WEIR}

The Saskatoon Public Library, like most city and regional libraries, has considerable information on natural history and conservation, most of which is non-technical, designed for general interest. Although some books deal with a specific topic, the treatment as a rule is intended for the layman.

An annotated listing of some of the recent additions to our library in the natural history area follows. Call numbers have been included for the convenience of those able to use Saskatoon Public Library. However, the call numbers may not be exactly the same in other libraries using the Dewey Decimal System. A person who wishes to read any of these books but finds it is not in his regional library, may obtain it on interlibrary loan by giving the librarian the author's name, title and the fact that the book is in the Saskatoon Public Library. The books can also be obtained by Saśkatchewan residents from the Provincial Library, Regina, by mail. There is no charge for either of these services.
'Logier, E. B. S., and G. C. Toner. 1961. Check-lis of the amphibians and reptiles of Alaska an Canada. Second Edition. Royal Ontario Museun Life Sciences Division, Contributions 53:1-92.

${ }^{4}$ Schmidt, K. P., and D. D. Davis. 1941. Field boo of snakes of the United States and Canada. G. I Putnam's Sons, New York.

Stebbins, R. C. 1966. A field guide to western rep tiles and amphibians. Houghton Mifflin Co Boston.

"Wright, A. H., and A. A. Wright. 1957. Handboo of snakes of the United States and Canada. Con stock Publishing Associates, Ithaca, New York

BARRINGTON, Rupert. The joys of a garde for your birds. 1972. How every garden of be turned into a sanctuary for many kinds wild birds.

598.2073 B27

BROWN, Dolores. Yukon trophy trail. 1971. The adventures of the first woman set foot on many of the big game trails of th Yukon.

799.297121 B87

BRUEMMER, Fred. Encounters with Arct animals. 1972. Superb photographs of No thern landscapes and animals, with an a count of the author's experiences while livir with the Eskimos.

599.0998 B88

COSTELLO, D. F. The world of the $g u$ 1971. All aspects of the gulls life cycle courtship and nesting habits, rearing young, colony formation, food, an migrations.

$598.33 \mathrm{C} 8$

COUSTEAU, J. Y. The whale, migh monarch of the sea. 1972. A beautiful illustrated narrative of the author's encou ters with sperm whales in the Pacific and I dian Oceans.

$599.5 \mathrm{C} 8$

CURRY-LINDAHL, Kai. Conservation $f$ survival. 1972. A programme for the $\mathrm{i}$ telligent use of the earth's renewable natur resources.

$333.72 \mathrm{C} 9$

CURRY-LINDAHL, Kai. Let them lit 1972. A worldwide survey of anime threatened with extinction. 591.042 C9

DAVIDS, R. C. How to talk to birds a other uncommon ways of enjoying nature $t$ year round. 1972. Unusual ways of enjoyi the woods, fields, marshes, and "even yo own backyard."

500.9 D2:

DURDEN, Kent. Gifts of an eagle. 197 The fascinating story of a golden eagle th spent sixteen years in captivity, giving $u$ swerving loyalty and affection to one $\mathrm{m}$ alone.

598.91 D9

FADIMAN, Clifton. Ecocide. 197 Thoughts toward survival by thirteen writ who examine the fundamental causes of a possible solutions to the ecological threat our world.

$301.31 \mathrm{~F} 1$ 